Електронне наукове фахове видання "Ефективна економіка" включено до переліку наукових фахових видань України з питань економіки

(Категорія «Б», Наказ Міністерства освіти і науки України від 11.07.2019 № 975) www.economy.nayka.com.ua | № 2, 2022|24.02.2022 p.

DOI: $10.32702 / 2307-2105-2022.2 .13$

УДК $658.14: 336.144$

O. Maslihan

Doctor of Economic Sciences, Associate Professor of the Department of Management,

Management of Economic Processes and Tourism, Mukachev State University

ORCID ID: 0000-0002-8465-548X

L. Kushch

Senior Lecturer of the Department of Hotel, Restaurant and Resort Industry, Higher Educational Institution of Ukoopspilka «Poltava University of Economics and Trade»

ORCID ID: 0000-0001-7493-5800

S. Dudnyk

Senior Lecturer of the Department of Hotel, Restaurant and Resort Industry, Higher Educational Institution of Ukoopspilka «Poltava University of Economics and Trade»

ORCID ID: 0000-0001-8228-7276

N. Goblyk-Markovych

PhD in Economics, Associate Professor of the Department of Management, Management of

Economic Processes and Tourism, Mukachev State University

ORCID ID: 0000-0001-05738-1842

\title{
IMPLEMENTATION OF THE SUSTAINABLE DEVELOPMENT PRIORITIES OF TOURISM AND HOTEL AND RESTAURANT CLUSTERS IN REGIONS OF UKRAINE
}

О. О. Маслиган,

д. е. н., доцент кафедри менеджменту, управління економічними процесами та туризму, Мукачівський державний університет

Л. I. Кущ,

старший викладач кафедри готельно-ресторанної та курортної справи,

Вищий навчальний заклад Укоопспілки «Полтавський університет економіки і торгівлі»

С. О. Дудник,

старший викладач кафедри готельно-ресторанної та курортної справи,

Вищий навчальний заклад Укоопспілки «Полтавський університет економіки і торгівлі»

Н. М. Гоблик-Маркович,

к. е. н., доцент кафедри менеджменту, управління економічними процесами та туризму, Мукачівський державний університет

\section{ІМПЛЕМЕНТАЦІЯ ПРИОРИТЕТІВ СТАЛОГО РОЗВИТКУ КЛАСТЕРІВ ТУРИЗМУ ТА ГОТЕЛЬНО-РЕСТОРАННОГО БІЗНЕСУ В РЕГІОНАХ УКРАЇНИ}

The presentation of priorities for the operation of the tourism, hotel, and restaurant clusters in regional development planning should take place within the framework of the translation of the regional objectives into an inherent process deriving from the intrinsic cluster nature. This process is carried out based on a systematic description of the purposeful actions of the cluster actors' associations outside the territory of cities, villages, and towns, which is an element in the search for the best solution for a specific situation. Consequently, the study defined the specifics of implementing the sustainable development of the tourism, hotel, and restaurant clusters priorities. 
In particular, the content of the process of finding a better solution for the specific sustainable development situation of the cluster is defined and the elements of the search for a better solution to the specific sustainable development situation of the tourism, hotel, and restaurant cluster are presented. The process of finding the best solution for the specific sustainability situation of the tourism, hotel, and restaurant clusters define as: in a plane of organizational stability; in a plane of technological stability; in a plane of financial stability. These elements are essential in ensuring the functionality of cluster members and methods of finding their paths development. This methodology should contain an algorithm for finding patterns in information arrays and meaningful interpretation of the obtained facts determines the order of action to approximate cluster actors to optimality parameters. Thus, the search for the best solution in terms of organizational sustainability should ensure a rhythmic process of providing tourist or hotel and restaurant cluster products. This process is linked to the dimensions of technological and financial sustainability. The search for the best solution in terms of technological stability should determine whether the business of each of the cluster actors uses its production capacity to the fullest extent. The search for the best solution in terms of financial stability focuses on determining the security of business in sub-areas of profitability, creditworthiness, and solvency.

Представлення пріоритетів функиіонування кластерів туристичного, готельного та ресторанного бізнесу в плануванні регіонального розвитку має відбуватися в межах переведення регіональних иілей в іманентний процес. Цей процес випливає з внутрішньої природи кластеру. Процес здійснюється на основі системного опису ијілеспрямованих дій об'єднань учасників кластера за територіями межах міст, сіл та селищ, щуо є базовим елементом пошуку найкращого рішення для конкретної ситуації. Відтак у дослідженні реалізоване визначення специфіки імплементації пріоритетів сталого розвитку кластерів туризму та готельно-ресторанного бізнесу. Зокрема, визначено зміст процесу пошуку найкращцого рімення для конкретної ситуації сталого розвитку кластера, представлено складові пошуку найкращуого рішення для конкретної ситуації сталого розвитку кластера туризму та готельно-ресторанного бізнесу. Процес пошуку найкращого рішення для конкретної ситуачії сталого розвитку кластерів туристичного та готельно-ресторанного бізнесу визначається: 1) у площині організаційної стійкості; 2) у площині технологічної стійкості; 3) у площині фінансової стійкості. Ці елементи основні у забезпеченні функиіональності учасників кластера та у пошуку траєкторії їх розвитку. Має бути наявний алгоритм пошуку закономірностей у масивах інформації та змістова інтерпретачія отриманих фактів, щзо визначає порядок дій $з$ наближення учасників кластерів до параметрів оптимальності. Так, пошук найкращого рімення у площині організаційної стійкості має бути спрямований на забезпечення ритмічного процесу надання окремих туристичних або готельно-ресторанних послуг або спільних продуктів кластеру. Цей прочес пов'язаний із площинами технологічної та фінансової стійкості. Пошук найкращого рімення у площині технологічної стійкості важливо спрямувати на визначення того, наскільки повно бізнес кожного з учасників кластеру використовує виробничі потужності. Пошук найкращуого рімення у площині фінансової стійкості орієнтований на оцінку бізнесу в субплощинах прибутковості, кредитоспроможності та платоспроможності.

Keywords: cluster; business; planes; product; service.

Ключові слова: кластер; бізнес; площини; продукт; послуга.

Problem-setting and its relation to important scientific or practical objectives. It's important to ensure the functionality of tourist, hotel and restaurant clusters. This functionality presupposes the creation of a wide range of possibilities for determining priority directions for ensuring the sustainable functioning of individual members, their associations and regions of Ukraine as a whole. The process involves the initiation and ongoing implementation of the cluster's sustainable development priorities, aimed at shaping an adequate impact on the development indicators of the region's tourism, hotel and restaurant sectors. These are indicators that can affect the ability of a regional system to operate in near-equilibrium conditions, with constant external and internal impacts. These should not be generic 
indicators, but indicators whose dynamics have an impact on the continuity of business (i.e., on individual cluster participants); on their development trajectory (it is important to select the indicators that will form the basis for setting prescriptions in cloud services of clusters). Only under such conditions will the cluster provide better indicators for the sustainable functioning of the region.

Analysis of recent studies and publications. As the main works in which the solution of the problem of implantation of priorities of sustainable development of tourism and hotel and restaurant business is started, we have selected: Bronshpak G.K., Chernyshov S.I. [2], Isakin M.A., Teplykh G.V. [2], Kyrylyuk L.M. [3], Kropel'nyts'ka, S.O. and Perederko, V.P. [4] etc. It's on these works that the authors rely in the meds of the outlined study. However, most of the work merely draws attention to the importance of the selection of indicators, the performance of which has an impact on the continuity of the business and its development trajectory. It's important to choose a single algorithm for finding patterns in information arrays and to ensure a meaningful interpretation of the findings regarding sustainable development priorities. However, the process of selecting these indicators is not separately investigated, although this is important. Only if such selection is implemented optimally, Machine learning and other artificial intelligence techniques analyze all the accumulated and processed data for each cluster member in the region and identify the order of action to approximate the optimality or predicted absolute (defined by existing development priorities).

Formulation of the objectives. Accordingly, the purpose of the article is to define the specifics of the implementation priorities of the sustainable development of the tourism, hotel, and restaurant clusters. The stated objective made it necessary to define the following research objectives: 1) to define the content of the process to find the best solution for the specific sustainable development situation of the cluster; 2) to the identification of the components of the search for the best solution for the specific sustainable development situation of the cluster.

Presentation of the material of the study, supporting the scientific results obtained. The presentation of priorities for the operation of the tourism and hotel and restaurant clusters in regional development planning should take place as part of decisions to translate regional goals into an inherent process, resulting from the intrinsic nature of such associations To find the best solutions for a specific sustainable development situation, marginal conditional targets are set for the implementation of sustainable development priorities in the cluster through the management analysis module. The module offers an ideal solution to practical problems that will benefit the permanent cluster and regional participants.

This process requires adjusting the requirements. It's based on the similarity of the algorithms for stable functioning relative to the spheres of activity (based on which a reference compact subset of parameters of a dynamic cluster medium or a so-called attractor is formed). This subset will be represented by the internal dynamics of the parameters and their internal functions. All trajectories of development of parameters of functioning of participants ensure permanence, provided that endlessly aspire to the standard. Attributes are fixed points (core indicator reference points); periodic trajectories (core indicator fluctuation); a defined cluster environment with indicators of sustainable development.

The process of finding the best solution for a specific sustainability situation of a cluster is defined as [6]: in a plane of organizational stability; in a plane of technological stability; in a plane of financial stability. Its elements are essential in ensuring the functionality of cluster actors and finding their development paths. There should be an algorithm for finding patterns in information arrays and interpreting the obtained facts, which determines the order of action to approximate the cluster actors to optimality parameters [7].

Thus, the search for the best solution in terms of organizational sustainability should aim at ensuring the continuity of tourism, hotel, and restaurant cluster products. Therefore, this process is linked to the dimensions of technological and financial sustainability [5; 6]. Looking for the best solution in a plane of technological stability, it is important to determine how well the business of each of the cluster members uses its production capacity.

The search for the best solution in terms of financial sustainability focuses on the determination of business security in sub-areas (profitability, creditworthiness, and solvency). Need a model that provides guaranteed returns and potential repayment opportunities to cluster participants through break-even models. As a matter of principle, the use as one of the fixed points of an attractor is based on the point of the break-even model in which the profits of cluster actors are equal to zero. Such a point would provide a solution to the scientific and practical problem of standardizing tourism, hotel, and restaurant production in value and kind [4].

The classical pattern of break-even, taking into account its disadvantages, should be optimized and adapted to the peculiarities of the functioning of the tourist and recreational cluster. On the main classical model, there is a transformed model of break-even, for the normalization of the production size of the common product. Fixed costs should be determined by dividing the groups of appreciably similar types of actors' products. Therefore, an additional quantity - the distribution base - is introduced into the break-even model (for rationing the output of a product). The distribution base is the total amount of the wage costs of employees (directly producing services) or the share of profits in the groups of conventionally similar types of products [6].

The specificity of sustainability will be based on ensuring that the actual volume of services provided consistently exceeds that of the attractor's real estate (break-even point). In this context, a margin of financial security will be ensured. It is a guarantee of profitability. It is defined as the arithmetic mean of individual values of conventionally similar types of products. The automation of this process in Cloud Big Data is possible through the application of cloud data preparation and analysis platforms (namely RapidMiner or KNIME, which implement visual programming and are capable of analyzing and modeling data). To find an ideal solution to the problem of standardizing the output of products based on the break-even model by an economic entity, in a cloud with the platform RapidMiner or KNIME can be given the option of using valid forecasting data. The platforms form a norm based on methods for extrapolating time series and a modified average relative to the rate of growth of notional similar types of 
products. Cloud Big Data uses RapidMiner to predict input indicators based on trend functions (by selecting curves that represent possible changes over time most accurately) that take into account the influence of all factors.

Based on the modified average, the characteristics of the curve equation (linear, exponential, logarithmic, polynomial, power) are calculated and the accuracy of the prediction is evaluated (based on the probability of approximation R2).

A pattern of change such that the probability of approximation is closest to 1 is appropriate. If it's not possible to determine the type of curves for trend indicators, the platform launches an algorithm of the modified average, relative to the rate of growth of the notionally similar types of tourist and hotel-restaurant products (the trend «biased average» is constructed).

The positive fact is that the use of the break-even point as fixed points of the attributor creates conditions for the introduction of the «operating lever» (hereinafter - EOL). The EOL is introduced as a supporting methodological algorithm to ensure the guaranteed profitability of cluster actors (by groups of conditionally similar types of products). The EOL is based on the estimation of the ratio of fixed and variable costs of business entities working in the cluster.

We note that with the increase of fixed costs in the operating costs of the cluster actors, the number of operating profit changes. The higher value of the operating lever is riskier for a cluster actor. It integrates the following factors: 1) the increase in operating surplus by the volume of products supplied, by groups of their notional types or as a whole; 2) the increase in the sensitivity of operating surplus to changes in cash flows. Normally, that sharp drop in the volume of services provided may increase the risk of a «domino effect» due to negative financial strength.

The solvency and creditworthiness of cluster actors can be formed only if a balanced attraction of credit, that is, the formation of a capital structure that will ensure the growth of profits through added value. There is a link between the creditworthiness and solvency of the cluster member and the composition of its capital, so it is advisable to isolate the two-tier financial lever and the solvency modality matrix as fixed points of the attributor.

However, a two-tier financial lever, as a fixed attractor, will only operate when debt capital is introduced into the liability structure of the cluster actors. This is because the growth of this balance sheet item automatically increases the financial burden, which has a significant negative impact on the capacity to pay while increasing the profitability of equity. These points are the means by which the scientific and practical problem of operational support for the value of the capital structure of a cluster member is ideally addressed.

The system of algorithms «financial lever» implies finding the ideal solution to the problem of optimizing the capital structure of the cluster actors, based on the integrated effects. The operational support for optimal equity values (with sufficient solvency) of the cluster member in the region is based on EFL+/EFFL inequality.

The importance of EFL should demonstrate that cluster actors prefer to accumulate cash forms of assets (as opposed to non-monetary forms). To effectively regulate EFL values, it is appropriate to construct a matrix to determine the forms of solvency. The assets of each cluster actors in the region are presented in several ways:

1) representation of assets by form (liquid expression) and content. Determination of the form of assets is carried out in monetary or non-monetary forms;

2) presentation of capital by ownership, in equity and debt, and in monetary or non-monetary forms, depending on the direction of advance.

The above-mentioned dependencies allow the expression of the property structure of the cluster actors in a two-level matrix, which generalizes unified balance sheet data in the following formats: static (where all liquidity assets are identified); dynamic (where all assets are identified with an emphasis on increments).

When a matrix is created, determining the solvency of a member of the tourism and hotel and restaurant cluster may be negative. In this case, structural optimization of the non-monetary value of the property is warranted. The optimization process should be carried out based on an extended trigger system. Consider it appropriate to greatest attention should be paid to the structure of non-monetary assets, which has the greatest impact: on the nature of the exchange, distribution, and financing operations; and on solvency and creditworthiness.

Optimization is appropriate based on triggers such as the Wilson model, the Miller-Orr model (which takes into account the chaotic nature of changes in cash balances by the time a certain limit is reached).

The best solution in terms of technological sustainability should be found in terms of the quality of tourist and hotel-restaurant products] (as this is the ultimate goal of upgrading the technology of the cluster actors). One of the most appropriate techniques for the technological control of the basic characteristics of the quality of a product is to be applied. The best method is the Ishikawa diagram. This method identifies the causes of quality problems and suggests their subsequent distribution to key categories that affect the characteristics of services (their ideal state forms fixed attractor points). The results make it possible to find an ideal solution to the problem from the point of view of ensuring that the services of the cluster actors (on which the level of satisfaction of the client depends) meet the established requirements.

The search for the best solution for a particular technological stability situation should be based on the identification of key product quality categories in the Ishikawa diagram. The reference state of key categories of technological quality should be described in a customized way - the Quality House». "House of quality" is a possible element of deployment of the components of technological quality. It is based on the understanding of the needs of the consumer of tourist and hotel-restaurant products, produced by the member of the cluster within the categories of technological quality (which can be measured qualitatively).

This process should translate consumer perceptions of the quality of tourist and hotel-restaurant products. It's implemented in the following order:

1) Defining consumer requirements and ranking them according to key categories of technological quality (Ishikawa diagram); 
2) Determination of the actual competitive ranking of the cluster actors among the other cluster members;

3) Determination of the reference standard for each category of technological quality. It is possible based on the characteristics of similar products produced within or outside the cluster;

4) Identification of the relationship between consumer requirements and the product reference state produced by the cluster actors;

5) Determination of the total increase in the technological resilience of the cluster actors (subject to a significant deviation from the benchmark or a low competitive rating).

In order to maintain a high level of technological stability of the cluster actors, it is necessary to separate algorithms of optimization of technological quality of the product of the cluster actors. According to the above, it is advisable to continuously monitor the level of the technical quality of the product in comparison with the production of competitors. An understanding of how best to approach the standard is emerging.

The general process characteristics of the cluster actors are as follows:

- a description of the processes, forms, and methods of customer service;

- characteristics of the customer service process;

- compositions of excursions, sights and gastronomic products;

- a list of hikes, walks, menus;

- a list of service providers;

- a typology, capacity or capacity of the equipment used;

- an insurance or confidentiality policy.

Each process characteristic of the production process is matched by individual measurement indicators (quantitative or qualitative). Therefore, the assessment of these characteristics should be carried out in a comparable manner. This is possible on the basis of a rating scale (taking into account the mutual influence on the actual competitive rating).

In order to identify the mutual influence of technological characteristics on each other and on the actual competitive rating, additional columns of roof type are formed as settings to «quality house».

Conclusions and prospects for further research. The presentation of priorities for the functioning of the tourism, hotel, and restaurant clusters in regional development planning should take place within the framework of translating regional goals into an inherent process. The process is carried out based on a systematic description of the targeted actions of the cluster members' associations in the territories of cities, villages, and townships. These combinations are the search element for the best solution for a particular situation.

The process of finding the best solution for the specific sustainability situation of the tourism, hotel and restaurant clusters is defined as: 1) in a plane of organizational stability; 2 in a plane of technological stability; 3) in a plane of financial stability.

These elements are essential in ensuring the functionality of cluster actors and in finding their development paths process. Logically, an efficient algorithm for finding patterns in information arrays and interpreting the obtained facts is needed, defining the order of actions on the approximation of cluster participants to optimality parameters.

Thus, the search for the best solution in terms of organizational sustainability should be aimed at ensuring a rhythmic process of providing tourist, hotel and restaurant products of the cluster. This process is therefore linked to technological and financial stability. Looking for the best solution in a plane of technological stability, it's important to determine how well each cluster member's business uses production capacity.

The search for the best solution in terms of financial sustainability focuses on the determination of business security in sub-areas profitability, creditworthiness, and solvency. In particular, an algorithm is needed to provide guaranteed returns and the potential for full and timely repayment of cluster actors' obligations through break-even models. An algorithm is needed that will ensure that a balanced credit attraction is possible, that is, the creation of a capital structure that will allow profit growth in the form of added value. An extended trigger system is needed if the monetary capital of the cluster member is negative.

Prospects for further research. The introduction of priorities for the sustainable development of the tourism, hotel, and restaurant business clusters in the regions of Ukraine will make it possible to balance the processes of the participants, cluster, and regional development. At the same time, minimizing the impact of threats to cluster development.

\section{References.}

1. Bronshpak, G.K. and Chernyshov, S.I. (2009), Model' Leont'eva v mikrojekonomike, strategija upravlenija dejatel'nost'ju klastera molochnogo profilja [Leontiev's model in microeconomics, dairy cluster management strategy], JSC Scientific and Technological Institute of Transcription, Translation and Replication, Kharkiv, Ukraine.

2. Isakin, M.A. and Teplyh, G.V. (2009), "Development Conditions of Clusters in the Perm Region Economic System", Regional'naja jekonomika: teorija i praktika, vol. 4, pp. 27-35.

3. Kyryliuk, L.M. (2014), "Prospects for tourism clusters in Podolia", Heopolytyka y ekoheodynamyka rehyonov, vol. 2 (13), no. 10, pp. 580-584.

4. Kropel'nyts'ka, S.O. and Perederko, V.P. (2016), "Conceptual framework for the development of a tourism cluster for the development of a newly integrated territorial community", Aktual'ni problemy rozvytku rehionu, vol. 12 (2), pp. 149-158. 
5. Muzychenko-Kozlovs'ka, O.V. and Muzychenko-Kozlovs'kyj, A.V. (2011), "Development of the management system of tourist clusters in Ukraine", available at: http://www.nbuv.gov.ua/portal/natural/Vnulp/Logistyka/2011_706/16.pdf (Accessed 01 March 2021).

6. Maslihan, O.O. and Kampov, N.S. (2019), "Methodological algorithms of sustained functioning of tourism and recreation enterprises in clusters", Economies' Horizons, no. 3 (10), pp. $54-65$.

7. Maslihan, O.O. and Korolovych, O.O. (2019), "Regional management paradigm of the integrated effort of development elements of recreation and tourism cluster", Economies' Horizons, no. 4 (11), pp. 23 -36.

\section{Список літератури.}

1. Броншпак Г.К., Чернышов С.И. Модель Леонтьева в микроэкономике, стратегия управления деятельностью кластера молочного профиля: монография. Харьков: АО "Научно-технологический институт транскрипции, трансляции и репликации". 2009. 323 с.

2. Исакин М.А., Теплых Г.В. Условия развития кластеров в экономической системе Пермского края. Региональная экономика: теория и практика, 2009. № 4. С. 27-35.

3. Кирилюк Л.М. Перспективи створення туристичних кластерів на території Поділля: Геополитика и экогеодинамика регионов. 2014. 2 (13). Т. 10. С. 580-584.

4. Кропельницька С.О., Передерко В.П. Концептуальні засади формування туристичного кластеру для розвитку новоствореної об'єднаної територіальної громади. Актуальні проблеми розвитку регіону. 2016. 12 (2). C. $149-158$.

5. Музиченко-Козловська О.В., Музиченко-Козловський А.В. Розвиток системи управління туристичними кластерами в Україні / O.В.Музиченко-Козловська 2011. URL: http://www.nbuv.gov.ua/portal/natural/Vnulp/Logistyka/2011_706/16.pdf

6. Maslihan O.O., Kampov N.S. Methodological algorithms of sustained functioning of tourism and recreation enterprises in clusters. Economies' Horizons. 2019. no. 3 (10). 54-65.

7. Maslihan O.O., Korolovych O.O. Regional management paradigm of the integrated effort of development elements of recreation and tourism cluster. Economies' Horizons. 2019. no. 4 (11). P. 23 -36. 